\title{
Aplikasi Media Terkondisi Sel Punca Mesensimal dalam Terapi Penyakit Degeneratif dan Penyembuhan Luka
}

\section{Application Of Mesenchymal Stem Cell Conditioned Medium In Degenerative Disease And Wound Healing Therapies}

\author{
Stefani Santi Widhiastuti \\ Prodi Biologi, Fakultas Teknobiologi, Universitas Atma Jaya Yogyakarta \\ Jl. Babarsari no.44, Sleman, Daerah Istimewa Yogyakarta, Indonesia \\ E-mail: stefani.santi@uajy.ac.id *Penulis untuk korespondensi
}

\begin{abstract}
Degenerative diseases such as stroke, heart disease, hypertension, and diabetesare diseases that are experienced by many people as they get older. Therapies with drugs and surgery have been widely used. However in some cases, the results have not been maximized. Asthe science and technology are getting advanced, stem cells are also developed as regenerative therapy, not only for the degenerative diseases treatment but also for wounds healing due to physical trauma and other diseases. One type of stem cell that is widely used is mesenchymal stem cells (MSC). Although stem cells have the potential to be developed as a therapy for degenerative diseases and wound healing, the differentiation process in body has not been maximum controlled. Therefore so many researchers have developed the use of mesenchymal stem cell conditioned medium (MSC-CM) as an alternative therapy. MSCCM which is a liquid medium where MSC grows has been shown to have an effect similar to MSC, so that it can be used in the treatments forstroke, heart disease, diabetes, and wound healing
\end{abstract}

Key words: Stem Cell, MSC, MSC-CM, degenerative disease, wound healing

\begin{abstract}
Abstrak
Penyakit degeneratif seperti stroke, jantung, hipertensi, dan diabetes merupakan penyakit yang banyak dialami seseorang seiring dengan bertambahnya usia. Terapi dengan obatobatan maupun dengan operasi telah banyak digunakan Namun pada beberapa kasus, hasilnya belum maksimal. Dengan meningkatnya ilmu pengetahuan dan teknologi, sel punca juga dikembangkan sebagai terapi regeneratif, tidak hanya untuk pengobatan penyakit degeneratif namun juga untuk penyembuhan luka akibat trauma fisik maupun penyakit yang lain. Salah satu macam sel punca yang banyak digunakan adalah sel punca mesensimal (SPM). Meskipun sel punca memiliki potensi untuk dikembangkan sebagai terapi penyakit degeneratif dan penyembuhan luka, namun proses diferensiasinya dalam tubuh belum terkontrol dengan maksimal, sehingga banyak peneliti mengembangkan penggunaan media terkondisi sel punca mesensimal (MT-SPM) sebagai terapi alternatif. MT-SPM yang merupakan medium cair tempat tumbuh SPM terbukti memiliki efek serupa dengan SPM, sehingga dapat digunakan dalam terapi penyakit stroke, jantung, diabetes, dan penyembuhan luka.
\end{abstract}

Kata kunci: Stem Cell, SPM, MT-SPM, penyakit degeneratif, penyembuhan luka

Diterima: 13 December 2019, disetujui: 30 January 2020

\section{Pendahuluan}

Penyakit degeneratif merupakan kondisi kesehatan dimana organ maupun jaringan mengalami penurunan fungsi secara terus menerus seiring berjalannya waktu. Penyebab utamanya adalah proses penuaan yang dialami oleh setiap manusia. Beberapa contoh penyakit degeneratif adalah stroke, jantung, hipertensi, diabetes, dan lain sebagainya. Berbagai macam terapi menggunakan obat-obatan maupun operasi telah banyak dikembangkan untuk pengobatan penyakit degeneratif. Dan seiring 
dengan berkembangnya ilmu pengetahuan dan teknologi, dikembangkan juga terapi menggunakan sel dan produk yang dihasilkan oleh sel.

Sel punca mesensimal merupakan salah satu sel punca yang potensial digunakan dalam pengobatan regeneratif. Sel punca mesensimal mampu memproduksi protein dan sitokin untuk perbaikan jaringan, zat imunomodulator yang dapat menekan inflamasi karena luka maupun karena penolakan oleh tubuh (Azarpira et al., 2015). Sel punca mesensimal tidak hanya potensial untuk dikembangkan sebagai terapi penyakit degeneratif, namun juga untuk pengobatan luka yang disebabkan oleh trauma fisik maupun penyakit lain.

Sel punca mesensimal (SPM) merupakan salah satu jenis sel punca yang terdapat pada sumsum tulang, jaringan adiposa, darah tali pusat, dan Wharton jelly dari tali pusat (Azarpira et al., 2015). SPM mampu memproduksi protein dan sitokin untuk perbaikan jaringan, zat imunomodulator yang dapat menekan inflamasi karena luka maupun karena penolakan oleh tubuh (Azarpira et al., 2015; Lozito et al., 2009), serta memiliki sifat pro-angiogenik ( $\mathrm{Xi} \& \mathrm{Bu}$, 2014).

Meskipun sel punca memiliki potensi untuk dikembangkan sebagai terapi penyakit degeneratif dan penyembuhan luka, namun proses diferensiasinya dalam tubuh belum terkontrol dengan maksimal, sehingga banyak peneliti mengembangkan penggunaan media terkondisi sel punca mesensimal (MT-SPM) sebagai terapi alternatif. MT-SPM yang merupakan medium cair tempat tumbuh SPM terbukti memiliki efek serupa dengan SPM (Wolbank et al., 2010).

\section{Sel Punca dan Pengobatan Regeneratif}

Sel punca atau stem cell adalah sel yang belum terspesialisasi dan dapat berkembang menjadi sel yang terspesialisasi dan memiliki fungsi baru. Sel punca ini memiliki dua karakteristik yang khas, 1) memiliki kemampuan untuk memperbarui dirinya sendiri (self renewal) melalui pembelahan sel secara mitotik dan 2) memiliki kemampuan berdiferensiasi menjadi berbagai macam tipe sel, jaringan, maupun organ yang spesifik. Sel maupun jaringan yang baru ini dapat memperbaiki atau mengganti kerusakan sel atau jaringan (The National Stem cell Foundation of Australia, 2015).

Sel punca berperan penting untuk perkembangan, pertumbuhan, pemeliharaan, dan perbaikan sel maupun jaringan di otak, tulang, otot, saraf, darah, kulit, dan organorgan tubuh yang lain. Karena kedua sifat tersebut, sel punca sangat potensial untuk dikembangkan sebagai pengobatan regeneratif pada berbagai penyakit (Kalra dan Tomas, 2014).

Pengobatan regeneratif (regenerative therapy) merupakan bidang bioteknologi yang mengkombinasikan berbagai aspek dan strategi pengobatan, termasuk penggunaan sel yang dihasilkan secara de novo untuk meningkatkan, memulihkan, atau menggantikan suatu jaringan yang rusak atau hilang, secara efektif memperbaikinya baik secara struktural maupun fungsional. Pengobatan regeneratif mencakup penggunaan faktor-faktor pertumbuhan (growth factor), biomaterial, dan sel punca (Mao dan Mooneya, 2015; Tatullo et al., 2015).

Pengobatan regeneratif berpotensi menyembuhkan atau menggantikan jaringan maupun organ yang rusak berdasarkan usia, penyakit dan trauma, serta menormalkan cacat bawaan. Data praklinis dan klinis menunjukkan kemungkinan penggunaan pengobatan regeneratif untuk penyakit akut maupun kronis (Mao dan Mooneya, 2015). Salah satu contoh penyakit regeneratif yang banyak diteliti untuk diterapi dengan sel punca adalah diabetes mellitus. World Health Organization (WHO) memprediksi kenaikan jumlah penyandang diabetes mellitus di Indonesia dari 8,4 juta pada tahun 2000 menjadi sekitar 21,3 juta pada tahun 2030 (Perkeni, 2015).

Para peneliti menyimpulkan bahwa sel punca mesensimal yang merupakan salah satu jenis sel punca, yang diambil dari sumsum tulang dapat menurunkan kadar glukosa darah dan C-peptida. Si et al. (2012) dalam penelitiannya membuktikan bahwa pemberian sel punca mesensimal dapat memperbaiki kondisi hiperglikemia pada tikus diabetes mellitus tipe 2. Kong et al. (2014) menggunakan sel punca mesensimal yang diderivatisasi dari sumsum tulang untuk terapi 
pada 18 pasien diabetes mellitus tipe 2 secara intravena.

\section{Sel Punca Mesensimal dan Media Terkondisi Sel Punca Mesensimal}

\section{Mesenchymal Stem Cells (MSCs)}

Mesenchymal Stem Cells (MSCs) atau sel punca mesensimal (SPM) merupakan salah satu jenis sel punca dewasa yang bersifat multipoten. SPM awalnya ditemukan pada sumsum tulang. Sekarang SPM telah dapat diisolasi dan dikarakterisasi dari beberapa jaringan dewasa dan juga janin, termasuk dari jaringan adiposa atau lemak, dermis, darah tali pusat, Wharton jelly dari tali pusat, plasenta, cairan amniotik, cairan sinovial, dan periosteum. Kemampuan multipotensi, aksi reparatif, kemampuan homing, dan sifat immunoregulator meningkatkan harapan penggunaan sel punca dalam pengobatan regeneratif dan mendorong banyak uji klinis yang dilakukan di seluruh dunia (Azapira et al., 2015; Kim et al., 2013; Murphy et al., 2013). Sel punca ini memiliki kemampuan untuk berdiferensiasi menjadi berbagai tipe sel. Kemampuannya ini memberikan peluang dalam pemanfaatannya sebagai sel terapi (Azapira et al., 2015).

Menurut Caplan (2019), sel punca mesensimal adalah nama yang pada awalnya diberikan kepada sekelompok sel yang melekat pada kultur dari sumsum tulang manusia dewasa, yang dapat diekspansi dan diinduksi untuk membentuk tulang keras, tulang rawan, otot dan jarinan kerangka lainnya dalam kultur. Dijelaskan lebih lanjut bahwa asal mula SPM ini diasumsikan sebagai jaringan ikat atau stroma sumsum tulang. SPM ini dapat diisolasi dari sejumlah jaringan yang mengalami vaskularisasi, serta muncul dari sel-sel perivaskular, pericytes.

Sel punca mesensimal tidak berdiferensiasi secara in vivo menjadi jaringan kerangka, melainkan berfungsi sebagai parakrin, yaitu pusat sekretori di lokasi cidera. Sel punca ini mampu memproduksi protein dan sitokin untuk perbaikan jaringan, zat imunomodulator yang dapat menekan inflamasi karena luka maupun karena penolakan transplantasi jaringan oleh tubuh (Azapira et al., 2015; Kay et al., 2017), serta sifat proangiogenik yang berpotensi untuk terapi (Xi dan $\mathrm{Bu}, 2014$ ).

Pernyataan tersebut memperkuat hasil penelitian yang pernah dilakukan oleh Murphy et al., (2013) yang menyebutkan bahwa SPM dapat berdiferensiasi menjadi berbagai jaringan, termasuk tulang keras, kartilago, dan adiposa. Namun yang berperan besar adalah fungsi trofik, parakrin dan imunomodulatornya (Kim et al., 2013).

Tidak seperti produk obat farmasetik yang mengadministrasikan suatu senyawa aktif dengan dosis spesifik untuk terapi suatu luka atau penyakit, SPM diregulasi untuk berada di lokasi yang membutuhkan dan menyekresikan senyawa-senyawa bioaktif serta sinyal-sinyal dengan konsentrasi berbeda-beda untuk menanggapi isyarat dari lingkungan mikro setempat.

Sel punca mesensimal juga bertindak sebagai pericytes penstabil kapiler darah. Pericytes ini akan distimulasi oleh growth factor menjadi SPM yang aktif, yang akan memberikan respon terhadap lingkungan mikronya dengan menyekresikan senyawa imunomodulator, senyawa antimikroba, serta sitokin dan senyawa trofik yang memiliki aksi mitogenik, angiogenik, neurogenik, antiinflamasi, antiapoptosis, perbaikan jaringan dan regenerasi. Selain itu, vesikel ekstraseluler seperti mikrovesikel dan eksosom diduga sebagai mediator kunci proses transfer informasi antara satu sel dengan sel yang lain dalam proses regenerasi (Caplan, 2019; Kim et al., 2013, dan Murphy et al., 2013).

Lebih lanjut, Caplan (2019) menjelaskan bahwa setelah lingkungan mikro dapat dibangun kembali dan berfungsi seperti sedia kala, maka SPM akan kembali ke bentuk semula sebagai perycites yang tidak aktif dan menempel pada pembuluh darah. SPM berperan sebagai gudang obat jika terjadi cidera atau peradangan. Kemampuan terapeutik SPM telah diuji untuk pengobatan multiple sclerosis, infark miokard akut, stroke, dan diabetes, serta keadaan klinis lainnya.

Meskipun mekanisme pasti dari aksi perbaikan oleh SPM masih belum jelas, namun sekretom dan mikrovesikel diduga kuat berperan penting pada proses regenerasi jaringan karena kemampuan immunomodulasinya, sehingga sekretom ini merupakan kandidat yang menjanjikan sebagai terapi bebas sel untuk penyakit 
neurodegeneratif (Kim et al., 2013, Murphy et al., 2013; Kay et al., 2017).

Kemajuan yang signifikan telah berhasil dilakukan dalam upaya memahami mekanisme biokimia dan metabolik, serta reaksi umpan balik yang terkait dengan respon SPM. Pemberian SPM secara alogenik telah dikategorikan sebagai obat dan telah banyak diaplikasikan. Penelitian terbaru menggunakan terapi SPM autolog menunjukkan kemanjuran terapi di berbagai tingkatan keparahan penyakit. SPM merupakan pilihan menarik untuk diaplikasikan dalam terapi regeneratif, antiinflamasi, dan autoimun (Murphy et al., 2013).

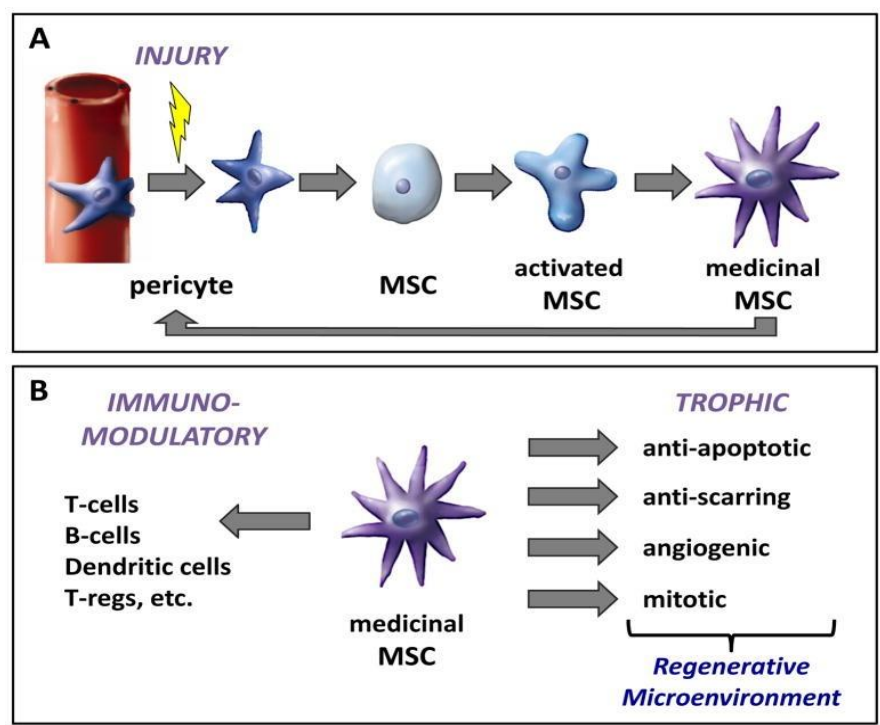

Gambar 1. A) Cidera atau kerusakan pembuluh darah menyebabkan perycites terlepas dari pembuluh. Selanjutnya pericytes dirangsang oleh growth factor terlarut dan kemokin menjadi MSC teraktivasi. MSC ini dimobilisasi ke lokasi cidera dan menjadi medicinal MSC yang merespon lingkungan mikro dengan mengeluarkan faktor-faktor yang memicu proses regenerasi lingkungan mikro. Setelah lingkungan mikro terbentuk kembali, MSC kembali ke keadaan pericyte asalnya yang melekat pada pembuluh darah. B) Molekul bioaktif yang dikeluarkan oleh Medicinal MSC adalah faktor-faktor trofik (senyawa mitogenik, angiogenik, anti-apoptosis atau pengurangan bekas luka), imunomodulator yang memengaruhi berbagai garis keturunan sel imun, serta faktor antimikroba (Caplan, 2011).

\section{Media Terkondisi Sel Punca Mesensimal (MT-SPM)}

Berbagai macam terapi menggunakan obat-obatan maupun melalui operasi telah dikembangkan untuk pengobatan bermacammacam penyakit degeneratif maupun penyakit yang disebabkan oleh trauma fisik. Selain itu juga dapat dilakukan transplantasi organ atau jaringan pada bagian yang mengalami kerusakan karena suatu penyakit. Transplantasi organ maupun jaringan ini memiliki tantangan tersendiri.

Diungkapkan oleh Azapira et al., (2015) transplantasi organ maupun jaringan memiliki beberapa keterbatasan, antara lain memerlukan tindakan pembedahan mayor, penolakan dari tubuh pasien terhadap jaringan maupun sel transplant, jumlah donor yang terbatas, maupun komplikasi yang mungkin terjadi setelah transplantasi.

Selanjutnya mulai dikembangkan terapi berbasis sel menggunakan sel punca, misalnya sel punca yang dihasilkan dari sumsum tulang, yang mengandung kumpulan sel seperti sel punca hematopoietik, sel punca mesensimal, dan sel progenitor endothelial merupakan pilihan yang menjanjikan untuk mengobati penyakit iskemik, termasuk penyakit iskemik jantung dan iskemik ekstremitas kronis (Bhang et al., 2014).

Meskipun demikian, proses penanaman sel punca ini tidak selalu berhasil. Jika proses penanaman kurang baik, maka sel-sel yang ditransplantasikan menjadi kehilangan efek terapeutiknya. Hal inilah yang menjadi keterbatasan terapi berbasis sel (Bhang et al., 2014 dan Kay et al., 2017). 
Terapi dengan sel punca memiliki kelemahan antara lain perlu investasi biaya yang besar, kultur sel yang mahal, proses handling sel yang tidak mudah, serta ketidaknyamanan pada saat prosedur pengambilan sel dari individu. Lebih lanjut, durasi bertahan hidup sel punca yang diimplantasi pendek dan tercatat menghilang beberapa minggu setelah transplantasi. SPM dari sumber autolog harus diambil dari pasien langsung dan dikultur secara in vitro sampai mencapai jumlah sel yang diharapkan (Cho et al., 2012; Kay et al., 2017; Ogata et al., 2018).

Selain itu terapi berbasis sel masih belum dapat dikontrol sepenuhnya. Beberapa penelitian menunjukkan adanya resiko sel punca hematopoietik yang berkembang menjadi sel kanker setelah transplantasi (Bhang et al., 2014; Gallagher dan Forrest, 2007; Kay et al., 2017).

Tingkat kelangsungan hidup yang rendah dan potensi tumorigenisitas sel yang diimplantasikan dapat merusak kemanjuran pengobatan berbasis sel. Hal inilah yang masih menjadi kekhawatiran tentang penggunaan sel punca dalam terapi selain permasalahan etika (Cho et al., 2012).

Untuk mengatasi keterbatasan tersebut maka dikembangkanlah media terkondisi sel punca. Media terkondisi merupakan media cair dimana sel punca ditumbuhkan dan dipelihara. Sebagai contoh, neovaskularisasi yang merupakan salah satu fitur yang terkenal dari terapi berbasis sel, dapat terjadi karena penggabungan sel punca transplant dengan pembuluh darah yang terbentuk. Beberapa bukti menunjukkan bahwa sinyal parakrin yang dikeluarkan oleh sel punca terlibat dalam sekresi berbagai macam growth factor yang berperan dalam angiogenesis, sehingga penyuntikan media terkondisi sel punca yang mengandung faktor angiogenesis merupakan alternatif terapi yang sangat potensial (Bhang et al., 2014; Cho et al., 2012; Kay et al., 2017).

Media terkondisi tempat tumbuh sel punca mesensimal yang belum berdiferensiasi disebut media terkondisi sel punca mesensimal (MT-SPM). Disebutkan oleh Wolbank et al. (2010) MT-SPM mengandung berbagai metabolit bioaktif yang memiliki efek serupa dengan sel punca mesensimal. Media ini mengandung growth factor (GF) proangiogenik maupun sitokin dan GF lain (Laqif, 2015). Growth factor berguna untuk memicu perkembangan fibroblast, sel endotelial, dan sel progenitor jaringan sehingga dapat mengarah pada regenerasi dan perbaikan jaringan (Davey, 2014).

Growth factor yang berperan dalam angiogenesis (penting dalam regenerasi jaringan/organ yang rusak) diantaranya adalah Vascular Endothelial Derived Growth Factor (VEGF), Fibroblast Growth Factor 2 (FGF2), Epidermal Grosth Factor (EGF), Hepatocyte Growth Factor (HGF), Placenta Growth Factor (PIGF), Stromal Derived Factor-1 (SDF-1), Platelet Derived Growth Factor (PDGF), Transforming Growth Factor-Beta (TGFß), dan Platelet Derived Endothelial Cell (PDEGF). Sitokin yang berperan dalam angiogenesis diantaranya adalah Interleukin, IL-8, kemokin, Monocyte Chemotactic Protein (MCP-1), leptin, angiogenin, dan endostatin/kolagen XVIII (Pawitan, 2014).

Media terkondisi SPM memiliki keunggulan seperti imunogenisitas rendah, berefek antiinflamasi, dan nontumorigenesis. Selain itu, media ini mudah untuk diproduksi secara masal, mudah disimpan pada suhu $20^{\circ} \mathrm{C}$ sampai dengan $-80^{\circ} \mathrm{C}$, mudah digunakan, serta karena tidak mengandung sel punca sehingga meminimalkan resiko berkembangnya kanker dan meminimalkan masalah etika yang mungkin muncul jika digunakan sel punca (Toda et al., 2007; Walter et al., 2014).

Kelebihan lain dari media terkondisi sel punca ini adalah dapat digunakan segera pada pasien tanpa perlu melakukan isolasi sel punca dari pasien tersebut terlebih dahulu dan tidak memerlukan kultur sel punca terus menerus seperti pada terapi sel (Bhang et al., 2014).

\section{Regulasi Angiogenesis}

Angiogenesis adalah proses pembentukan pembuluh darah baru yang terjadi secara normal dalam tubuh, dan merupakan proses alamiah yang berperan penting dalam proses dari pertumbuhan, perkembangan, penyembuhan luka, dan reproduksi. Berdasarkan beberapa penelitian yang menganalisa level VEGF, dapat disimpulkan bahwa yang paling banyak disekresikan oleh sel punca adalah VEGF. VEGF ini berperan pada angiogenesis, sehingga penting untuk regenerasi jaringan maupun organ yang rusak atau hancur. VEGF dapat menghambat apoptosis pada kondisi 
hipoksia, sehingga mencegah kerusakan lebih parah pada jaringan (Pawitan et al., 2014).

Dalam medium terkondisi sel punca terdapat berbagai macam faktor yang bekerja sama secara harmonis untuk meningkatkan regenerasi. Seperti dikatakan oleh Pawitan et al., (2014) bahwa penting untuk dapat menganalisis satu paket lengkap growth factor dan level sitokin untuk setiap medium terkondisi dari sel punca untuk mengetahui kondisi kultur, proses pengkondisian medium, serta penyakit yang responsif terhadap terapi dengan medium terkondisi tertentu.

Lebih lanjut, selain VEGF, growth factor lain yang terdapat pada MT-SPM dan memiliki peran pada angiogenesis adalah FGF2, HGF, PIGF, SDF-1, PDGF, TGF $\beta 1$, IGF-1, dan PDEGF. Selain itu, interleukin, kemokin seperti monocyte chemoattractant protein (MCP)-1, leptin, angiogenin, dan endostatin juga memiliki peran pada angiogenesis. FGF2 lebih poten sebagai angiogenik daripada VEGF, dengan berefek pada proliferasi fibroblast, preadiposit, dan sel punca endotelial, epitelial, maupun neural (Bhang et al., 2014; Katagiri et al., 2017; Ogata et al., 2018; Pawitan et al., 2014).

Berbagai macam faktor parakrin yang dikeluarkan oleh sel punca mesensimal tersebut tidak hanya memiliki peran angiogenesis, namun juga dapat mempercepat migrasi sel punca ke lokasi yang memerlukan sehingga mempercepat proses regenerasi jaringan di tempat tersebut (Ogata et al., 2018).

Penelitian yang dilakukan oleh Katagiri et al., (2017) berfokus pada VEGF dalam MTSPM dan mengevaluasi potensi angiogenik dan osteogenik dari MT-SPM pada regenerasi tulang. Mereka memiliki hipotesis bahwa angiogenesis merupakan tahapan penting pada proses regenerasi tulang, dan VEGF merupakan salah satu faktor penting yang dapat meningkatkan potensi osteogenik.

\section{Aplikasi MT-SPM dalam Terapi Penyakit Degeneratif dan Penyembuhan Luka}

\section{Stroke dan Infark Miokardium}

Cho et al., (2012) mengevaluasi pengaruh pemberian media terkondisi sel punca terhadap tikus Sprague-Dawley yang diinduksi stroke iskemik. Dalam penelitian tersebut, media terkondisi sel punca terbukti dapat melawan stroke pada hewan model. Efek dari MT-SPM ini kemungkinan diperoleh dari peningkatan proliferasi sel endotelial, penurunan apoptosis sel neural, dan astrogliosis yang lebih ringan.

Studi terbaru yang telah dilakukan membuktikan bahwa efek terapi dengan sel punca pada infark miokard dimediasi oleh faktor parakrinnya. Sama halnya seperti penyakit stroke, salah satu tujuan utama pengobatan infark miokard adalah perbaikan pembuluh darah. Pemberian MT-SPM secara intravena pasca infark miokard pada babi dapat meningkatkan kepadatan kapiler dan mempertahankan fungsi jantung. Dengan potensi angiogenik yang dimilikinya, MT-SPM dapat meningkatkan perfusi miokard dan menormalkan aliran darah di jantung (Timmers et al., 2011).

Profil islet Langerhans pada kelompok perlakuan (gambar 1C) hampir sama dengan kelompok kontrol normal (gambar 1A), berbentuk bulat telur dengan jumlah sel normal di islet Langerhans lebih banyak daripada kelompok kontrol diabetes, memiliki batasbatas sel yang jelas dengan bentuk sel bulat.

\section{Gangguan Ginjal}

Gangguan pada ginjal dan aliran darah seringkali menyebabkan penyakit hipertensi. Chronic Kidney Disease (CKD) adalah salah satu gangguan ginjal yang banyak dialami oleh jutaan orang di seluruh dunia. Saat ini pengobatan utamanya adalah dengan hemodialisis maupun transplantasi ginjal. Keduanya memiliki keterbatasan dalam aplikasinya. Hemodialisis memerlukan pengorbanan waktu, biaya, dan tenaga karena harus dilakukan secara rutin terus menerus. Sedangkan translantasi ginjal memiliki permasalahannya sendiri, yaitu sulitnya mencari donor organ yang sesuai. Sangat penting untuk menghilangkan penyebab penyakitnya terlebih dahulu untuk memperlambat keparahan CKD dan sambil mencari terapi yang efektif (Van koppen et al., 2012 dan Liu et al., 2018).

Ketika terjadi kerusakan ginjal, maka hampir semua tipe sel di ginjal terlibat dalam proses perbaikannya dan mensekresikan matriks ekstraseluler, antara lain sel mesangial, 
sel enfotelial, podosit, sel renal tubular, dan fibroblast intersisial. Di sisi lain, sel mononuklear, makrofag, limfosit, dan sel inflamasi lain juga terlibat dalam perbaikan jaringan melalui jalur yang berbeda (Liu et al., 2018).

Liu et al. (2018) dalam penelitiannya mengevaluasi penggunaan media terkondisi sel punca mesensimal dari tali pusat manusia (hucMSC-CM) untuk terapi renal tubulointerstitial inflammation dan fibrosis. Fibrosis ginjal sendiri ditandai dengan inflitrasi dari sel inflamasi dan pelepasan mediator inflamasi, aktivasi dan proliferasi fibroblast, dan deposisi matriks ekstraseluler. Dalam penelitian tersebut, hucMSC-CM menurunkan deposisi matriks ekstraseluler dan inflitrasi sel inflamasi pada tikus yang diinduksi fibrosis ginjal dengan unilateral ureteral obstruction (UUO), hal ini menunjukkan bahwa media terkondisi sel punca mesensimal dari tali pusat manusia mampu melindungi ginjal dari kerusakan oleh UUO.

Pada penelitian lain yang dilakukan oleh Overath et al., (2016) menunjukkan bahwa media terkondisi sel punca mesensimal dari jaringan adiposa yang diprekondisikan hipoksia dapat meningkatkan regenerasi tikus model gangguan ginjal akut. Media terkondisi ini secara signifikan dapat memperbaiki nilai kreatinin serum dan neutrofil gelatinase, serta level sitokin inflamasi IL-1 $\beta$ dan IL-6.

Sel punca mesensimal dari sumsum tulang telah terbukti berkontribusi pada perbaikan nefropati diabetik, namun perannya belum dikarakterisasi secara menyeluruh. Nagaishi et al., (2016) menginvestigasi pengaruh pemberian media terkondisi sel punca mesensimal yang mensekersikan parakrin dan eksosom pada nefropati diabetik. Eksosom yang dimurnikan dari MT-SPM memberikan efek anti-apoptosis dan melindungi struktur tight junction pada sel epithelial tubular ginjal. Dalam penelitian tersebut ternyata MT-SPM bekerja sama baiknya dengan SPM, ditunjukkan dengan keduanya sama-sama menghambat eksaserbasi albuminuria. Terapi dengan MT-SPM ini sangat potensial untuk mencegah nefropati diabetik melalui berbagai aksinya melindungi ginjal.

\section{Diabetes}

Diabetes mellitus tipe 2 merupakan jenis diabetes dengan prevalensi paling tinggi dengan berbagai kemungkinan komplikasi. Hingga saat ini telah bermacam-macam terapi yang digunakan untuk pengobatan DM tipe 2, mulai dari terapi dengan menggunakan Obat Antidibetik Oral (OAO), suntik insulin, maupun operasi. Namun masing-masing terapi tersebut masih memiliki keterbatasan dalam aplikasinya (Widhiastuti et al., 2018; Amini et al., 2018).

Widhiastuti et al., (2018) dalam penelitiannya menyebutkan bahwa pemberian 0,1 cc MT-SPM dapat menormalkan kadar glukosa darah pada tikus model diabetes tipe 2 . Hasil uji histopatologi pankreas juga menunjukkan peningkatan jumlah sel-sel Langerhans, artinya pada tikus model DM tipe 2 yang diberi perlakuan MT-SPM mengalami regenerasi sel. Penelitian serupa dilakukan oleh Branitamahisi (2017), dimana pada penelitian tersebut tampak perbaikan sensitivitas insulin oleh MT-SPM melalui peningkatan ekspresi gen IRS-1tyr612 pada tikus model DM tipe 2.

Luka juga merupakan permasalahan klinis yang seringkali terjadi pada orang dengan riwayat diabetes. Luka pada pasien diabetes seringkali sulit untuk sembuh karena terganggunya migrasi keratinosit dan proses proliferasi, serta kurangnya oksigenasi ke daerah luka yang disebabkan aliran darah tidak lancar karena kadar glukosa yang tinggi dalam darah dan peradangan yang terjadi di tempat luka. MT-SPM dapat mempercepat penyembuhan luka pada hewan model diabetes melalui mekanisme angiogenesis dan immunomodulasi (Li et al., 2015; Irons et al., 2018).

\section{Rheumatoid Arthritis (RA)}

Rheumatoid Arthritis (RA) merupakan penyakit autoimun dan kronis yang ditandai oleh peradangan sendi tulang rawan dan erosi tulang. Penyakit ini dapat menyebabkan hiperglasia, edema, dan penurunan aktivitas motorik di daerah yang mengalami peradangan (Kay et al., 2017; Nazemian et al., 2016).

Hingga saat ini belum ada obat yang dapat benar-benar menyembuhkan RA. Terapi yang dilakukan pada pasien RA antara lain disease modifying anti-rheumatic drugs (DMARDs) atau obat-obatan yang menekan sistem imun. Selain itu, terapi juga dapat 
dilakukan secara biologis dengan anti-TNF $\alpha$, anti-IL1, anti-IL6R, anti-CD20 dan T-cell costimulation blockers. Meskipun demikian, tidak semua pasien akan merespon obat-obatan yang diberikan, bahkan beberapa ada yang menimbulkan efek samping seperti resiko infeksi, hipertensi, dan kemungkinan timbulnya limfoma. Selain itu, injeksi harus diberikan secara berkelanjutan dan memerlukan biaya yang mahal (Kay et al., 2017).

Dalam penelitiannya, Kay et al., (2017) mengevaluasi potensi terapeutik dari MT-SPM sebagai alternatif pengobatan RA. Efek terapi MT-SPM dibandingkan langsung dengan SPM melalui pengukuran hasil akhir histologi, produksi TNF- $\alpha$ dan hilangnya tulang rawan. Dari penelitian tersebut diperoleh hasil, baik SPM maupun MT-SPM dapat meningkatkan konsentrasi IL-10, yaitu sitokin yang memiliki efek pleiotrofik pada sistem kekebalan dan peradangan. MT-SPM memiliki efek terapi yang serupa dengan SPM. Perlakuan dengan MT-SPM dapat menurunkan kerusakan kartilago dan menekan respon imun dengan menurunkan pembelahan aggrecan, meningkatkan fungsi Treg, dan menyesuaikan rasio Treg : Th. MT-SPM dapat memberikan terapi bebas sel yang efektif untuk radang sendi.

Nazemian et al., (2016) menyebutkan bahwa penyuntikan MT-SPM setiap hari secara intraperitonial selama 21 hari setelah penyuntikan Complete Freund's Adjuvant (CFA) pada tikus model dapat mengurangi tanda-tanda inflamasi seperti hiperglasia dan edema pada berbagai tingkat keparahan. Penyuntikan CFA dosis tunggal secara subkutan dapat menginduksi arthritis pada tikus model.

Efek parakrin dari MT-SPM dapat memperbaiki kondisi inflamasi yang terjadi. Medium terkondisi sel punca mesensimal dari jaringan adiposa memiliki efek immunosupresif terhadap Th17/Treg pada pasien RA. Faktor sekretori yang diproduksi oleh SPM terbukti memiliki efek imunoregulator terhadap sel Th17 dan Treg, serta dapat menghambat jalur sitokin efektor utama: produksi TNF-a, IL-17, IL-21 pada RA in vitro (Vasilev et al., 2019).

\section{Perbaikan Jaringan Rusak dan Penyembuhan Luka}

Sel punca mesensimal telah terbukti memiliki kemampuan untuk memperbaiki jaringan yang rusak dan mempercepat penyembuhan luka melalui efek parakrin yang dihasilkan. Selain itu, SPM yang berasal dari sumsum tulang dapat memperbaiki kerusakan jaringan dengan cara menghambat apotosis dan fibrosis, serta menyekresikan sejumlah senyawa bioaktif yang memediasi perbaikan jaringan. Kemampuan ini juga dimiliki oleh media terkondisi sel punca mesensimal (Zhou et al., 2013).

Pada tahun 2014 Jun et al., melakukan penelitian menggunakan media terkondisi sel punca mesensimal yang diperoleh dari cairan amnion manusia. Dalam penelitian tersebut MT-SPM yang dikondisikan hipoksia terbukti dapat mempercepat penyembuhan luka. Kondisi hipoksia tidak hanya meningkatkan proliferasi MT-SPM dari cairan amnion, namun juga menjaga sifat konstitutifnya seperti ekspresi marker dan potensi diferensiasi.

Faktor parakrin seperti VEGF dan TGF$\beta 1$ yang disekresikan ke medium terkondisi dalam keadaan hipoksia lebih banyak daripada pada kondisi normal. Secara in vitro, MT-SPM yang dikondisikan hipoksia dapat lebih meningkatkan proliferasi dan migrasi fibroblast dan penutupan luka ada kulit manusia dibandingkan MT-SPM pada kondisi normal. Mekanisme penyembuhan luka ini diperkirakan terjadi melalui jalur aktivasi TGF- $\beta /$ SMAD2 dan PI3K/AKT, dimana pada kondisi hipoksia semakin banyak faktor parakrin yang dikeluarkan (Jun et al., 2014).

Sel punca mesensimal memang telah terbukti dapat memperbaiki kerusakan jaringan melalui sinyal parakrin (Amini et al., 2018). Chen et al. pada tahun 2014 melakukan penelitian yang bertujuan membandingkan pengaruh kondisi kultur sel normoksia dan hipoksia terhadap ekspresi dan sekresi molekul parakrin sel punca mesensimal dari sumsum tulang, meliputi sitokin, growth factor, dan kemokin yang berdasarkan hipotesis berkontribusi terhadap penyembuhan luka.

Pengujian dengan reverse transcriptase polymerase chain reaction (RT-PCR) dan enzyme-linked immunosorbent assay (ELISA) menunjukkan bahwa pada kondisi hipoksia sinyal parakrin yang dikeluarkan lebih banyak, sehingga pada media terkondisi sel punca mesensimal di bawah kondisi hipoksia 
disekresikan lebih banyak Vascular Endothelial Derived Growth Factor A (VEGFA), Fibroblast Growth Factor (bFGF), interleukin 6 (IL-6) dan interleukin 8 (IL-8). Sejalan dengan hasil tersebut, maka proses penyembuhan luka pada tikus Balb/c yang diterapi dengan MT-SPM pada kondisi hipoksia jauh lebih cepat daripada yang diterapi dengan MT-SPM pada kondisi normal (Chen et al., 2014).

\section{Perbaikan Kerusakan Hati}

Pada tahun 2013, Du et al. melakukan penelitian yang bertujuan untuk mengetahui apakah MT-SPM dapat melindungi hepatosit dan sinusoidal endothelial cells (SECs), serta merangsang regenerasi organ hati yang ditransplantasikan dengan ukuran 50\% lebih kecil dari ukuran normal atau 50\% reducedsize liver transplantation (RSLT).

Terapi SPM sendiri terbukti dapat mencegah hilangnya sel parenkim dan mendorong perbaikan jaringan melalui aksi trofik, molekul yang disekresikan. Penelitian ini dilakukan pada tiga kelompok tikus penelitian. Kelompok pertama sebagai kelompok yang dioperasi palsu, kelompok kedua adalah kelompok tikus RSLT yang menerima MT-SPM, dan kelompok ketiga adalah kelompok tikus RSLT yang hanya menerima medium.

Berdasarkan penelitian tersebut MTSPM dapat mencegah pelepasan biomarker cidera hati, menghasilkan pengurangan apoptosis hepatosit dan SEC sehingga meningkatkan kelangsungan hidup tikus secara signifikan. Selain itu pada kelompok yang diterapi dengan MT-SPM terdapat peningkatan ekspresi VEGF, peningkatan jumlah sel hepatosit dan SEC masing-masing 1,2 dan 1,6 kali lipat, penurunan tingkat ekspresi beberapa proinflamasi dan penurunan yang nyata infiltrasi neutrofil dan aktivasi sel Kupffer. Hasil penelitian ini menunjukkan bahwa MTSPM pada terapi RSLT memberikan dukungan trofik pada hati yang terluka dengan menghambat kematian hepatosit dan SEC, serta merangsang regenerasi keduanya (Du et al., 2013).

Hasil ini sejalan dengan penelitian yang dilakukan oleh Xagorari et al., (2013), dimana MT-SPM dapat memperbaiki kerusakan pada hepatosit tikus C5/B16 yang diciderai dengan induksi karbon tetraklorida (CCl4) secara intraperitonial. Kerusakan hati akut merupakan kondisi serius dengan tingkat kematian yang tinggi. Pada tikus dengan kerusakan hati yang diterapi dengan MT-SPM terjadi peningkatan interleukin-6 (IL-6) pada hari pertama dan diikuti dengan peningkatan ekspresi fibroblastlike-protein (FGL1) setelah 48 jam. Hal ini berkaitan dengan penurunan annexin $\mathrm{V}$ yang merupakan marker untuk apoptosis pada hari ketiga. IL-6 akan menginduksi ekspresi FGL1 yang selanjutnya menurunkan apoptosis dini melalui aktivasi FGL1.

\section{Perbaikan Kerusakan Tulang dan Osteogenesis}

Sel punca mesensimal dari sumsum tulang telah diteliti sebagai pilihan untuk terapi regenerasi tulang (Yamada et al., 2013). Sekretom dari sel punca mesensimal yang berasal dari sumsum tulang sebelumnya juga telah dilaporkan oleh Ogata et al., (2018) berpotensi kuat mempercepat regenerasi tulang. Langkah awal yang paling penting untuk regenerasi tulang adalah migrasi sel osteoprogenitor ke bagian tulang yang rusak atau cacat. Migrasi ini menjadi awal proses angiogenesis di lokasi tersebut. MT-SPM dilaporkan dapat meningkatkan migrasi sel punca endogen lebih awal ke bagian yang luka dan meningkatkan regenerasi jaringan tulang dan periodontal pada tikus model yang mengalami cacat tulang calvarial.

Sel punca mesensimal dari sumsum tulang telah diteliti sebagai pilihan untuk terapi regenerasi tulang (Yamada et al., 2013). Sekretom dari sel punca mesensimal yang berasal dari sumsum tulang sebelumnya juga telah dilaporkan oleh Ogata et al., (2018) berpotensi kuat mempercepat regenerasi tulang. Langkah awal yang paling penting untuk regenerasi tulang adalah migrasi sel osteoprogenitor ke bagian tulang yang rusak atau cacat. Migrasi ini menjadi awal proses angiogenesis di lokasi tersebut. MT-SPM dilaporkan dapat meningkatkan migrasi sel punca endogen lebih awal ke bagian yang luka dan meningkatkan regenerasi jaringan tulang dan periodontal pada tikus model yang mengalami cacat tulang calvarial.

Medium terkondisi sel punca mesensimal juga mempercepat pembentukan kalus pada tikus model high-speed distraction osteogenesis (H-DO). Pada penelitian yang dilakukan oleh Ando et al., (2014) diketahui 
bahwa sekretom dari SPM menghambat inflamasi dan apoptosis, dan memicu diferensiasi osteoblast, angiogenesis dan proliferasi sel. Penelitian tersebut mengindentidikasi MCP-1/-3 dan IL-1/-6 sebagai faktor penting dalam merekrut murine bone marrow stromal cells (mBMSCs) untuk regenerasi jaringan tulang.

Hal serupa juga diungkapkan oleh Wang et al., (2012). Dalam penelitiannya, Wang mengungkapkan bahwa MT-SPM dapat menyembuhkan fraktur pada tikus model diabetes. Faktor penting dalam proses penyembuhan fraktur adalah aliran darah yang cukup ke tempat luka, yang umumnya sulit tercapai pada pasien diabetes. VEGF dan IL-6 yang terkandung dalam MT-SPM membantu pembentukan pembuluh darah baru yang dapat meningkatkan suplai darah ke lokasi fraktur dan mempercepat penyembuhan.

\section{Perbaikan Kerusakan Mata}

Kejernihan kornea mata sangat dipengaruhi oleh kondisi sel-sel endotelium. Kerusakan pada sel endotelium kornea dan hilangnya sejumlah sel dapat memicu gangguan penglihatan yang parah. Untuk mengatasi permasalahan tersebut, transplantasi kornea masih menjadi pilihan utama. Namun kemampuan proliferasi sel-sel endotel kornea manusia sangat terbatas. Hal ini menantang peneliti untuk mengembangkan teknik yang lebih efisien untuk membudidayakan healthy corneal endothelium cells (HCEC).

Pada penelitian yang dilakukan oleh Nakahara et al., (2013), MT-SPM yang diambil dari sumsum tulang belakang digunakan untuk ekspansi HCEC. Pada penelitian tersebut, MT-SPM terbukti tidak hanya memfasilitasi migrasi dari HCEC, merangsang proliferasi HCEC dengan mengatur protein G1 dari siklus sel, tetapi juga mempertahankan fenotipe yang dibedakan dengan karakteristik yang diperlukan untuk fungsi endotel.

\section{Perbaikan Jaringan dan Regenerasi Rambut}

Rambut seringkali diibaratkan sebagai mahkota seseorang. Rambut yang sehat dan tebal dapat meningkatkan kepercayaan diri seseorang, sehingga alopecia atau kebotakan rambut menjadi salah satu permasalahan yang sangat diperhatikan. Pertumbuhan rambut dipengaruhi oleh sel-sel induk yang berasal dari adiposa. Sel-sel ini akan mensekresikan berbagai faktor pertumbuhan yang mendorong pertumbuhan rambut.

Pada penelitian yang dilakukan oleh Fukuoka dan Suga (2015) diperoleh hasil terjadi peningkatan jumlah rambut secara signifikan pada pasien alopecia yang ditreatment dengan media terkondisi sel punca yang diturunkan dari jaringan adiposa dan disuntikkan secara intrademal dibandingkan dengan kelompok placebo. Hal ini menunjukkan media terkondisi sel punca dari jaringan adiposa efektif untuk mengatasi alopecia dan dapat menjadi solusi baru untuk terapi regenerasi rambut.

Media terkondisi sel punca dari jaringan adiposa kaya akan faktor pertumbuhan seperti vascular endothelial growth factor (VEGF), hepatocyte growth factor (HGF), plateletderived growth factor (PDGF), dan insulin-like growth factor 1 (IGF-1). VEGF mengontrol pertumbuhan rambut dan ukuran folikel rambut melalui proses angiogenesis. HGF terlibat dalam siklus pertumbuhan folikel rambut. PDGF menginduksi dan menjaga fase anagen atau pertumbuhan kantung pada folikel rambut. IGF-1 mengontrol siklus pertumbuhan rambut dan diferensiasi batang rambut. Masing-masing faktor pertumbuhan dapat mengaktivasi folikel rambut dan berkontribusi dalam meningkatkan jumlah helai rambut pada pasien alopecia.

\section{Simpulan}

Media terkondisi sel punca mesensimal memiliki aktivitas angiogenesis seperti sel punca mesensimal. Berbagai macam growth factor yang terdapat pada MTSPM berpotensi digunakan dan dikembangkan tidak hanya untuk pengobatan penyakit degeneratif, namun juga penyembuhan luka yang disebabkan oleh trauma fisik maupun penyakit lain. Dan tanpa adanya sel, penggunaan MTSPM dalam terapi berbagai peyakit lebih aman dan minim resiko.

\section{Daftar Pustaka}

Amini, A., P., R., Abdolahifar, M.A., Abbaszadeh, A.A., Ghoreishi, S.K., Chien, S., dan Baya, M. 2018. Stereological and Molecular Studies on The Combined 
Effects of Photobiomodulation and Human Bone Marrow Mesenchymal Stem Cell Conditioned Medium on Wound Healing in Diabetic Rats. $J$ Photoch Photobio B. 182: 42-51.

Ando, Y., Matsubara, K., Ishikawa, J., Fujio. N., Shohara, R., Hibi, H., Ueda, M., dan Yamamoto, A. 2014. Stem CellConditioned Medium Accelerates Distraction Osteogenesis Through Multiple Regenerative Mechanisms. Bone. 61: 82-90.

Azapira, N., Kavianil, M., Salehi, S. 2015. The Role of Mesenchymal Stem Cells in Diabetes Mellitus. Int J Stem Cell Res Ther. 2(2): 1-5.

Bhang, S.H., Lee, S., Shin, J.Y., Lee, T.J., Jang, H.K., dan Kim, B.S. 2014. Efficacious and Clinically Relevant Conditioned Medium of Human Adipose-derived Stem Cells for Therapeutic Angiogenesis. The American Society of Gene \& Cell Therapy 22(4): 862-872.

Branitamahisi, B., 2017. Perbaikan Sensitivitas Insulin Diabetes Melitus Tipe 2 oleh Media Terkondisi Sel Punca Mesensimal. Praxis 1(2).

Caplan, A.I. 2019. Principles of Regenerative Medicine (Third Edition), Chapter 15 Mesenchymal Stem Cells in Regenerative Medicine. Academic Press 219-227.

Caplan, A. I., 2011, The MSC: An Injury Drugstore, Cell Stem Cell, 9(1): 11-15

Chen, L., Xu, Y., Zhao., J., Zhang, Z., Yang, R., Xie, J., dan Qi, S., 2014. Conditioned Medium from Hypoxic Bone MarrowDerived Mesenchymal Stem Cells Enhances Wound Healing in Mice. PLoS One 9(4):e96161

Cho, Y.J., Song, H.S., Bhangm S.H., Lee, S., Kang, B.G., Lee, J.C, An, J., Cha, C.I., Nam, D.H., Kim, B.S., dan Joo, K.M., 2012. Therapeutic Effects of Human Adipose Stem Cell-Conditioned Medium on Stroke. Journal of Neuroscience Research 90(9): 1794-1802.

Davey, G.C., Patil, S.W., O’Loughlin, A., dan O’Brien, T.. 2014. Mesenchymal Stem Cell-Based Treatment for Microvascular and Secondary Complications of Diabetes mellitus. Front Endocrinol 5: 116.
Du, Z., Wei, C.W., Cheng, K., Han, B., Yan, J., Zhang, M., Peng, C., dan Liu, Y. 2013. Mesenchymal Stem Cell-Conditioned Medium Reduces Liver Injury and Enhances Regeneration in Reduced-Size Rat Liver Transplantation. Journal of Surgical Research. 183(2): 907-915.

Fukuoka, H. dan Suga, H., 2015. Hair Regeneration Treatment Using Adipose-Derived Stem Cell Conditioned Medium: Follow-up with Trichograms. EPlasty 15: 65-72.

Gallagher, G. dan Forrest, D.L. 2007. Second Solid Cancers After Allogeneic Hematopoietic Stem Cell Transplantation. Cancer 109: 84-92.

Irons, R.F., Cahill, K.W., Rattigan, D.A., Marcotte, J.H., Fromer, M.W., Chang, S., Zhang, P., Behling, E.M., Behling, K.C., dan Caputo, F.J. 2017. Acceleration of Diabetic Wound Healing with AdiposeDerived Stem Cells, EndothelialDifferentiated Stem Cells, and Topical Conditioned Medium Therapy in A Swine Model. J Vasc Surg. 68(6): 115S-125S.

Jun, E.K., Zhang, Q., Yoon, B.S., Moon, J.H., Lee, G., Park, G., Kang, P.J., Lee, J.J., Kim., A., dan You, S. 2014. Hypoxic Conditioned Medium from Human Amniotic Fluid-Derived Mesenchymal Stem Cells Accelerates Skin Wound Healing through TGF- $\beta /$ SMAD2 and PI3K/Akt Pathways. Int. J. Mol. Sci. 15: 605-628.

Kalra, K. dan Tomar, P.C. 2014. Stem Cells: Basics, Classification and Applications. Am J Phytomed Clin Ther. 2(7): 919930.

Katagiri, W., Kawai, T., Osugi, M., Wakayama, Y.S., Sakaguchi, K., Kojima, T., dan Kobayashi, T. 2017. Angiogenesis in Newly Regenerated Bone by Secretomes of Human Mesenchymal Stem Cells. Maxillofacial Plastic and Reconstructive Surgery. 39: 8.

Kay, A.G., Long, G., Tyler, G., Stefan, A., Broadfoot, S.J., Piccinini, A.M., Middleton, J., dan Kehoe, O., 2017. Mesenchymal Stem CellConditioned Medium Reduces Disease Severity and Immune Responses in Infammatory Arthritis. Scientific Reports 7:18019.

Kim, H.O., dan Choi, S., 2013. Mesenchymal Stem Cell-Derived Secretome and Microvesicles as A Cell Free 
Therapeutics for Neurodegenerative Disorders. Tissue Engineering and Regenerative Medicine 10(3): 93-101.

Laqif, A. 2015. Kajian Terapi Media Terkondisi Sel Punca Mesensimal (MT-SPM) Selaput Amnion pada Kasus Kegagalan Ovarium Prematur (Penelitian pada Hewan Coba Tikus Sprague-Dawley). Disertasi: Fakultas Kedokteran Universitas Gadjah Mada.

Li, M., Zhao, Y., dan Hao, H. dai, H., Han, Q., Tong, C., Liu, J., Han, W., dan Fu, X. 2015. Mesenchymal Stem CellConditioned Medium Improves the Proliferation and Migration of Keratinocytes in a Diabetes-Like Microenvironment. Int J Low Extrem Wounds. 14(1).

Liu, B., Ding, F., Hu, D., Zhou, Y., Long, C., Shen, L., Zhang, Y., Zhang, D., Dan Wei, G., 2018. Human Umbilical Cord Mesenchymal Stem Cell Conditioned Medium Attenuates Renal Fibrosis by Reducing Inflammation and Epithelial to Mesenchymal Transition via the TLR4/NF-Kb Signaling Pathway In Vivo and In Vitro. Stem Cell Research and Therapy 9(7).

Mao, A.S. dan Mooneya, D.J. 2015. Regenerative Medicine: Current Therapies and Future Directions. PNAS. 112(47).

Murphy, M.B., Moncivais, K., dan Caplan, A.I., 2013. Mesenchymal Stem Cells: Environmentally Responsive Therapeutics for Regenerative Medicine. Exp Mol Med 45(11): e54.

Nakahara, M., Okumura, N., Kay, E.P., Hagiya, M., Imagawa, K. 2013. Corneal Endothelial Expansion Promoted by Human Bone Marrow Mesenchymal Stem CellDerived Conditioned Medium. PLoS ONE 8(7): e69009.

Nagaishi, K., Mizue, Y., Chikenji, T., Otani, M., Nakano, M., Konari, N., dna Fujiyama, M., 2016. Mesenchymal Stem Cell Therapy Ameliorates Diabetic Nephropathy Via the Paracrine Effect of Renal Trophic Factors Including Exosomes. Scientific Reports 6 (34842).

Nazemian, V., Nasseri, B., Manaheji, H., dan Zaringhalam, J., 2016. Effects of Mesenchymal Stem Cells Conditioned Medium on Behavioral Aspects of Inflammatory Arthritic Pain Induced by
Complete Freund's Adjuvant. J Cell Mol Anesth. 1(2): 47-55.

Ogata, K., Osugi, M., Kawai, T., Wakayama, Y., Sakaguchi, K., Nakamura, S., dan Katagiri, W. 2018. Secretomes of mesenchymal stem cells induce early bone regeneration by accelerating migration of stem cells. Journal of Oral and Maxillofacial Surgery, Medicine, and Pathology. 30: 445-451.

Overath, J.M., Gauer, S., Obermüller, N., Schubert, R., Schäfer, R., Geiger, H., dan Baer, P.C., 2016. Short-Term Preconditioning Enhances the Therapeutic Potential of Adipose-Derived Stromal/Stem CellConditioned Medium in CisplatinInduced Acute Kidney Injury. Exp Cell Res 342(2): 175-83.

Pawitan, J.A. 2014. Prospect of Stem Cell Conditioned Medium in Regeneration Medicine. Biomed Res Int. 1: 1-14.

Perkeni, 2015, Konsensus Pengelolaan dan Pencegahan Diabetes Melitus Tipe 2 di Indonesia, PB PERKENI, p.1-2.

The National Stem Cell Foundation of Australia and Stem Cell Australia. 2015. The Asutralian Stem Cell Handbook. The University of Melbourne Australia.

Tatullo M., Marrelli M., Paduano F. 2015. The Regenerative Medicine in Oral and Maxillofacial Surgery: The Most Important Innovations in the Clinical Application of Mesenchymal Stem Cells. Int. J. Med. Sci., 12(1) : 72-77.

Timmers, L., Lim, S.K., Hoefer, I.E., Arslan, F., Lai, R.C., Van Oorschot, A.A., Goumans, M.J., Strijder, C., Sze, Sk., Choo, A., Piek, J.J., Doevendans, P.A., Pasterkamp, G., dan De Kleijn, D.P., 2011. Human Mesenchymal Stem CellConditioned Medium Improves Cardiac Function Following Myocardial Infarction. Stem Cell Research 6(3): 206-214.

Toda, A., Okabe, M., Yoshida, T., dan Nikaido, T. 2007. The Potential of Amniotic Membrane/Amnion-Derived Cells for Regeneration of Various Tissues. $J$ Pharmacol Sci. 105: 215-228.

Walter, MNM., Wright, K.T., Fuller, H.R., Mac Neil. S., Jognson, W.E.B. 2014. Mesenchymal Stem Cell-Conditioned Medium Accelerates Skin Wound Healing: An In Vitro Study of Fibroblast 
and Keratinocyte Scratch Assays. Experimental Cell Research. 316: 271281.

Wang, C.Y., Yang, H.B., Hsu, H.S., Tsai, K.S., Yew, T.L., Kao, Y.H., dan Hung, S.C., 2012. Mesenchymal Stem CellConditioned Medium Facilitates Angiogenesis and Fracture Healing in Diabetic Rats. J Tissue Eng Regen Med. 6(7):559-69.

Widhiastuti, S.S., Branitamahisi, B., Inayati, N.S., Kusuma, I.A.P, HAndika, D.B., Sadewa, A.H., Haryana. S.M., dan Laqif, A., 2018. Pengaruh Media Terkondisi Sel Punca Mesensimal (MT-SPM) terhadap Histopatologi Pankreas Tikus Model DM Tipe 2. Biota 3(3): 111-116.

Wolbank, S., Martijn van Griensven, GrillariVoglaurer, R.G., dan Peterbauer-Scherb, A. 2010. Alternative Sources of Adulth Stem Cells: Human Amniotic Membrane.

AdvBiochemEngin/Biotechnol, 123: 127.

Xagorari, A., Siotou, E., Yiangou, M., Tsolaki, E., Bougioklis, D., Sakkas, L., Fassas, A., dan Anagnostopoulos, A. 2013. Protective Effect of Mesenchymal Stem Cell-Conditioned Medium on Hepatic Cell Apoptosis After Acute Liver Injury. Int J Clin Exp Pathol. 6(5): 831-840.

Xi, Y. dan Bu, S. 2014. Stem Cells Therapy in Diabetes Mellitus. J Stem Cell Res Ther. 4: 199.
Yamada, Y., Nakamura, S., Ito, K., Umemura, F., Hara, K., Nagasaka, T., Abe, A., Baba, S., Furuichi, Y., Izumi, Y., Klein, O.D., Wakabayashi, T. 2013. Injectable Bone Tissue Engineering Using Exanded Mesenchymal Stem Cells. Stem Cells. 31(3): 572-580.

Van Koppen, A., Joles, J.A., Van Balkom, B.W.M., Lim, S.K., De Kleijn, D., Giles, R.H., dan Verhaar, M.C., 2012. Human Embryonic Mesenchymal Stem CellDerived Conditioned Medium Rescues Kidney Function in Rats with Established Chronic Kidney Disease. PLoS ONE 7(6): e38746.

Vasilev, G., Goycheva, M.I., Todorova, E.I., Yuzeir, K.T., Kurteva, E., Stoilov, R., Dan Kyurkchiev, D., 2019. Conditioned Medium from Adipose Mesenchymal Stem Cell Exert Immunosuppressive Effect on Th17/Treg Axis in Rheumatoid Arthritis In Vitro. Conference Paper in Annals of the Rheumatic Diseases 78 (Suppl 2):1074.2-1075.

Zhou, B.R., Xu, Y., Guo, S.L., 2013. The Effect of Conditioned Media of Adipose-Derived Stem Cells on Wound Healing after Ablative Fractional Carbon Dioxide Laser Resurfacing. BioMed Research International vol. 2013. 